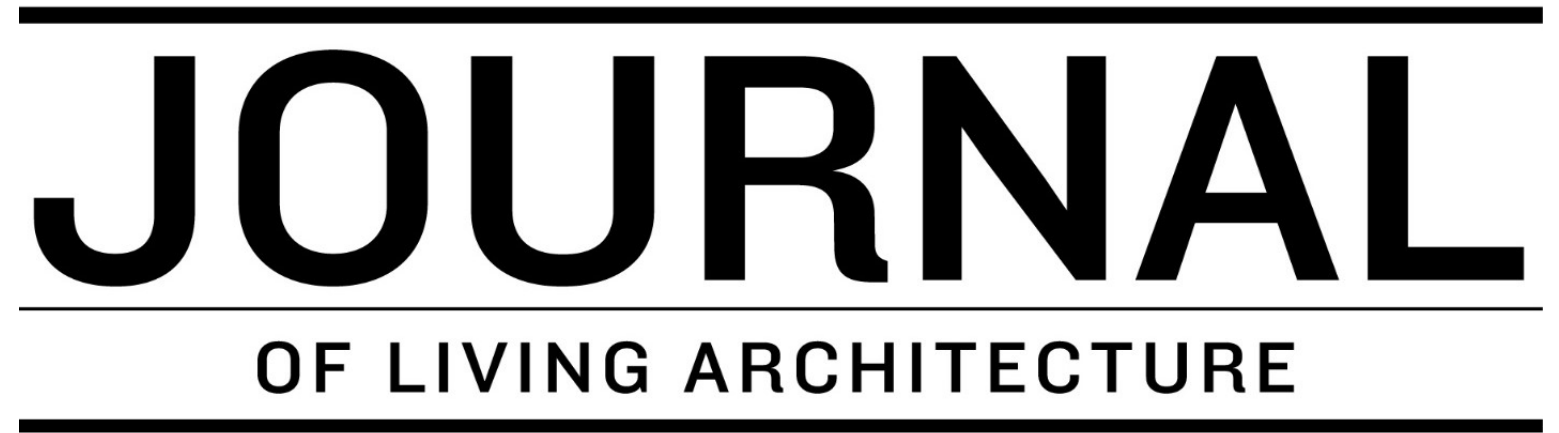

A GREEN ROOFS FOR HEALTHY CITIES PUBLICATION

\title{
Evaluating the potential stormwater retention of a living retaining wall system
}

\author{
M. Ostendorf ${ }^{1}$, S. Morgan ${ }^{1}$, S. Celik ${ }^{1}$, and W. Retzlaff*1 \\ ${ }^{1}$ SIUE Living Architecture Regional Center of Excellence, Box 1608, Southern Illinois University Edwardsville, \\ Edwardsville, IL 62026 \\ *corresponding author: wretzla@siue.edu
}

\begin{abstract}
Redesigning standard revetment or retaining walls to capture stormwater could increase the use of living walls and, thus, expand their beneficial impacts, including greening underutilized space. This study evaluated the potential stormwater retention and percent plant coverage of an experimental wall surface for six treatments (five vegetated Sedum treatments and an unplanted 'control' wall) on 18 circular living retaining wall systems designed from a standard retaining wall system. Percent stormwater retention, which compared effective precipitation volumes with stormwater runoff volumes, was quantified for 81 storm events from July 2010 to September 2011. Living retaining wall systems planted with $S$. (Phedimus) takesimensis retained stormwater more effectively than the unplanted wall and other planted treatments, including walls planted with S. spurium, mixed Sedum species, and S. kamtschaticum. Plant surface coverage of the living retaining wall system was the greatest when planted with mixed Sedum species, S. spurium, and S. kamtschaticum. Overall this study demonstrates that properly designed living retaining wall systems may be able to be used as a best management practice for stormwater retention in urban areas. Further study could determine the performance of living retaining walls with a more conventional design (i.e., single aspect vs. four aspects against a slope), over a longer time period, walls planted with other vegetated treatments, and walls featuring different fill and plant materials.
\end{abstract}

Key words: living wall, green infrastructure, stormwater management

This peer-reviewed article is provided free and open-access. 


\section{INTRODUCTION}

Cities have emerged as the core of modern human activity. Only $28 \%$ of the U.S. population resided in metropolitan areas in 1910 , but by 2010 , urban and suburban areas held $82 \%$ of the population (Population Division 2011). The relentless sprawl of cities decreases vegetation, fundamentally alters hydrology, and exacerbates environmental problems. Urban development increases impervious surface (roads, parking lots, driveways, roofs, etc.), that negatively affect hydrologic processes, including stormwater infiltration, groundwater storage, and evapotranspiration rates. In an urbanized watershed in St. Charles County, MO, as urban space increased from $3.4 \%$ to $27.3 \%$ between 1982 and 2003, the surface runoff increased $70 \%$ (Li and Wang 2009).

Remnant green spaces (e.g., urban forests, parks, and even landscaped lawns), though often dwarfed in size compared to impervious surface areas within heavily-urbanized areas, can positively impact urban watersheds by promoting groundwater storage, moderating stormwater flow, and increasing evapotranspiration, thus cooling the surrounding area. Simply connecting impervious surfaces with vegetated space can also promote greater infiltration and groundwater recharge. Routing stormwater from a gutter onto a lawn, for example, can reduce or slow runoff compared to routing a gutter onto a driveway and eventually into a nearby stormwater drain. Established lawns which are 50 years or older, may promote higher levels of infiltration than recently-established lawns (Mueller and Thompson 2009).

\section{Stormwater management}

An array of traditional stormwater control practices provides relief to urban areas, but relentless urban expansion makes mitigating stormwater an increasingly difficult task. Previously, urban centers perceived precipitation inflow as a menace, so management typically promoted quick drainage through storm sewer systems and channelized or straightened waterways. Some municipalities combined stormwater systems into traditional wastewater systems, forming a combined sewer system in an effort to save material, labor, and money. Unfortunately, during heavy rain events, inundated combined systems can discharge stormwater with untreated wastewater into local waterways (Parikh et al. 2005). Continued development within and surrounding the city further stresses the combined infrastructure and compounds the risk for combined sewer overflows (CSO), flooding (Villarreal et al. 2004), and basement backups. Stormwater best management practices, such as retention and detention basins, are effective tools, but they require acreage that is difficult to obtain in dense urban environments (Czemial Berndtsson 2010, USEPA 2006a, USEPA 2006c).

Innovative multifunctional practices have been developed that conserve space, serve the urbanized watershed during rain events, and meet other needs of the population (Carter and Jackson 2007). Sustainable drainage systems (SuDS) in the UK, and low impact development (LID) in North America, decentralize stormwater runoff, utilize available space more efficiently, and promote vegetative interception, evapotranspiration, and filtration. The innovation of green infrastructure (green roofs, rain gardens, living walls, etc.) has emerged as an alternative practice for moderating stormwater runoff while increasing green space. 


\section{Living walls}

One innovative green technology and potential stormwater management tool is the living wall, a vertical structure covered with vegetation typically planted in engineered substrate. Living walls seek to mimic naturally occurring vertically-oriented environments: plants clinging to cliff faces, vines climbing tree trunks, succulents attaching to rocky outcrops, etc. There are two conventional types of living walls, continuous and modular walls. Continuous designs involve lightweight screens, while modular designs can employ trays, vessels, planter tiles, or flexible bags (Manso and Castro-Gomes 2015). Living walls, also called green walls or vertical gardens, are typically used on building façades and other structures. Green wall systems are often employed in an effort to reduce noise levels (Azkorra et al. 2015, Romanova et al. 2019), but they are also reputed to reduce stormwater runoff and alleviate the urban heat island effect.

Standard soil revetment and retaining walls are designed to prevent soil erosion. Retaining walls are specifically used to support soil at a steep slope and are common solutions for developing urban sites with significant slopes. They are designed to allow water to pass through them. Redesigning standard retaining walls as living retaining walls to capture part of the stormwater through the use of growth media and plants could potentially expand the use of living retaining wall systems to new areas and, thus, expand their beneficial impacts.

The purpose of this study was to evaluate the environmental benefits of a standard retaining wall system designed to be used as a living retaining wall by quantifying differences in the stormwater retention between planted and unplanted model retaining walls. The study also compared plant wall coverage by different species of Sedum. It was hypothesized that planted living retaining walls would retain stormwater by a greater percentage than unplanted walls through evaporation from the growth media and evapotranspiration from the plants. It was also hypothesized that retaining walls planted with different Sedum plantings would differ in plant coverage.

\section{METHODS}

To investigate the effect of sun position, this research began with the construction of 18 experimental circular plantable living retaining wall systems on the Southern Illinois University Edwardsville (SIUE) campus in 2007. The walls utilized patented Hercules ${ }^{\mathrm{TM}}$ (St. Louis Retaining Wall Company, 12901 Saint Charles Rock Road, St. Louis, MO) standard retaining wall modules donated by the inventor, who wanted to determine if plants could survive in them and if the system could potentially be used to retain stormwater. Each wall was arranged with five circular tiers of blocks, staggered at each tier (Figure 1, background).

While the top of a standard retaining wall would typically be at the level of an impermeable surface (such as a road or parking lot) or a permeable surface (such as a grassy area), the experimental design was not. This design was to ensure obtaining adequate replications for each sun exposure (north, south, east, and west). Therefore, the calculations and results for stormwater retention are for precipitation on the wall itself, i.e., without any runoff from an adjacent surface. 
Each wall was approximately $2.13 \mathrm{~m}$ in diameter at the base, $1.68 \mathrm{~m}$ in diameter at the top, and approximately $69 \mathrm{~cm}$ tall. The core of each circular wall was filled with coal bottom ash recycled from a local coal-fired generation facility. Typical extensive green roof media is primarily inorganic, so bottom ash $(80 \%$ by volume) blended with composted pine bark $(20 \%$ by volume) was then applied to the pocket of each block and along the top surface of each circular wall system to a depth of $5 \mathrm{~cm}$. Therefore, the volume of growth media available in the pockets was much less than the volume of media filling the circular wall.

Each living wall system was constructed over an impermeable base layer with a single, central outlet to facilitate stormwater collection (Figure 1a). Installation of water collection units, 20.4 L buckets connected to the wall outlets with $3.8 \mathrm{~cm}$ PVC, was completed on June 28, 2010 (Figure 1b). This experimental design does not permit evaluation of base flow that would be expected with traditional installations of retaining walls.
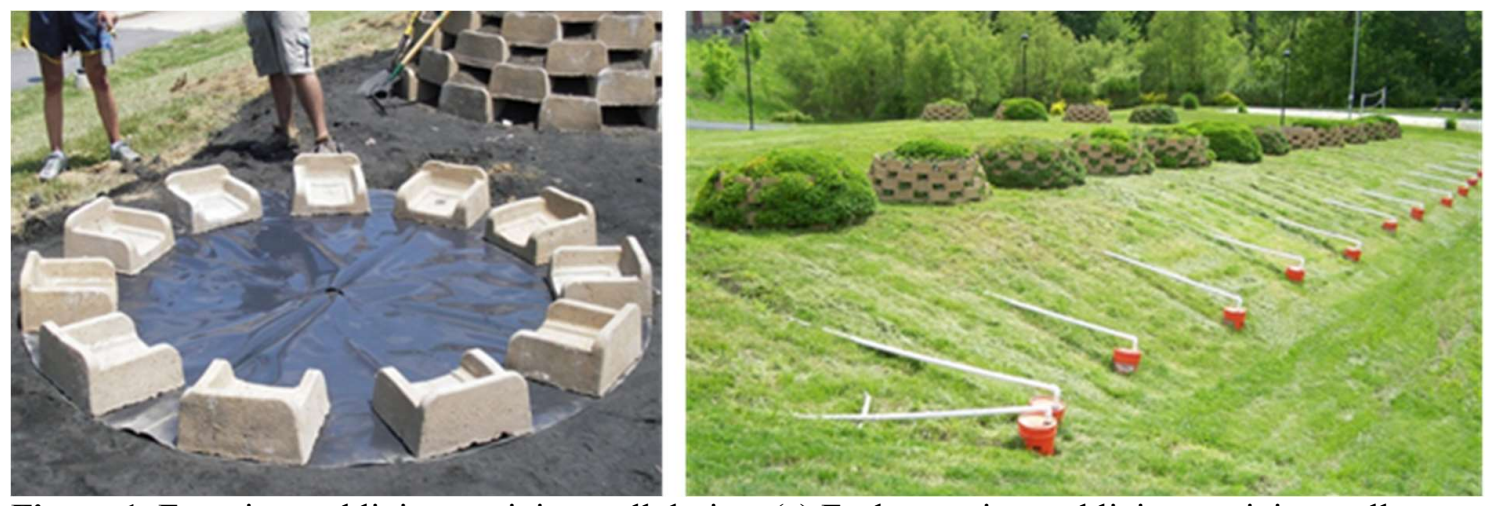

Figure 1. Experimental living retaining wall design. (a) Each experimental living retaining wall system was designed with an impervious base layer that drained to a middle collection hole (Foreground). Blocks were arranged in 5 staggered tiers (Background). (b) Each experimental living retaining wall system was also fitted with 20.4 L stormwater collection units (June 2010).

Five vegetative treatments and an experimental control wall (left unplanted), all with three replications, were arranged in a completely randomized design (Figure 1b). Each non-control wall was originally planted on July 1, 2007 with one of five Sedum species (S. kamtschaticum, S. (Phedimus) takesimensis, S. spurium, S. hybridum 'Immergrauch', or S. cauticola). Many of the $S$. cauticola plantings did not survive the first winter, so that planting treatment was replanted in spring 2008 with mixed plugs containing six Sedum species: S. spurium, $S$. sexangulare, $S$. cauticola, $S$. kamtschaticum, $S$. rupestre and $S$. album. All vegetated walls received supplemental plantings on September 17, 2010 and May 5, 2011 to facilitate dense vegetative coverage and to deter weed growth. No supplemental irrigation was provided during establishment or the study period. The living walls were fertilized annually with $5.3 \mathrm{~g}$ per wall pocket of Woodace (Lebanon Seaboard Corporation, Lebanon, PA) 18-5-10 long-term fertilizer.

\section{Plant coverage measurements}

Plant coverage of the living retaining wall surface was quantified using a dot grid template with $4 \mathrm{~cm}$-diameter holes spaced $1.1 \mathrm{~cm}$ apart and arranged in 13 rows and six columns. Wall 
coverage was measured on the north-, south-, east-, and west-facing aspects for each treatment. For each aspect at one location, the coverage template was clipped over the top block and draped over the side (Figure 2). The number of holes not containing vegetation were counted and recorded. Total living wall coverage, determined by adding together the empty spaces recorded from all aspects, was used to calculate percent coverage for each treatment using the equation:

$$
\% \text { Coverage }=\left[\frac{(312-\# \text { empty holes })}{312}\right] \times 100
$$

For $100 \%$ coverage, there were no open holes and vegetation completely concealed the wall blocks and growth media. Coverage was measured at monthly intervals for each replicate wall throughout the growing seasons of the study period, August through October 2010 and March through September 2011.

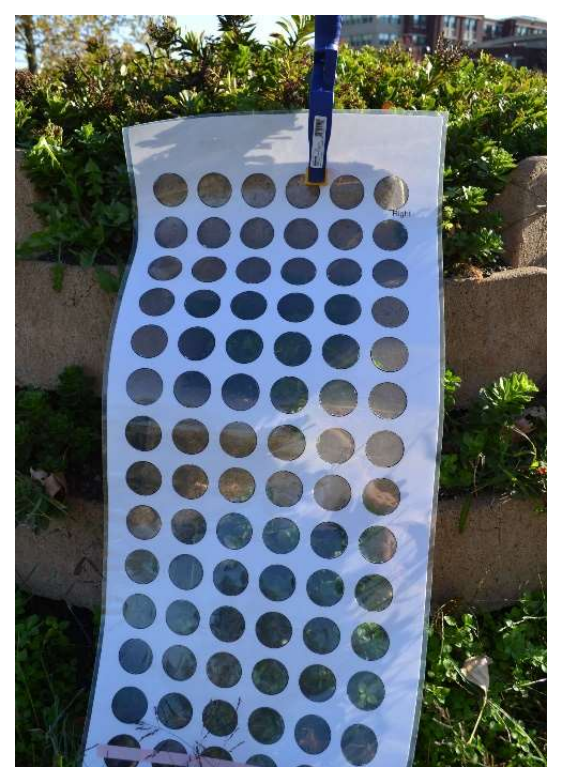

Figure 2. Plant coverage was determined on each treatment aspect using a dot grid template.

\section{Stormwater retention}

The volumes of stormwater that passed through the wall systems following precipitation events (every event from July 1, 2010 to September 15, 2011) were collected and quantified using 20.4 L collection units. The water level for each treatment was determined using a metric ruler placed flush to the inside of the collection unit. Collected stormwater volume was calculated using the recorded water levels and regression equations previously developed in the lab (Figure 3).

The collected stormwater volume was compared with the precipitation volume to determine percent retention. The percent retention of stormwater for each treatment was calculated employing the equation:

$$
\% \text { Retention }=\left[\frac{\left(V_{p}-V_{g w}\right)}{V_{p}}\right] \times 100
$$

where $\mathrm{V}_{\mathrm{p}}$ is the volume of precipitation that fell over each $2.13 \mathrm{~m}$ diameter living wall and $\mathrm{V}_{\mathrm{gw}}$ is the volume of stormwater collected from each circular wall system. 


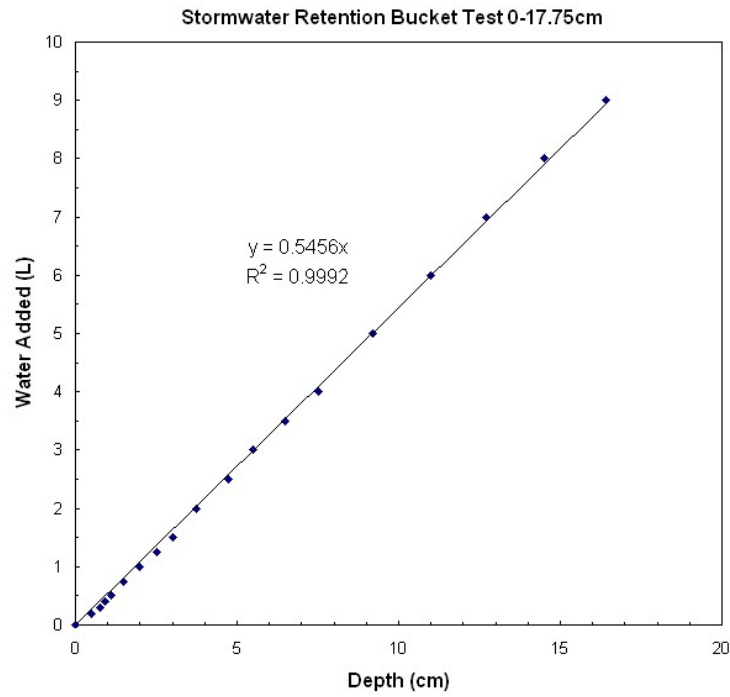

a)

Figure 3. Regression equations for stormwater collection buckets as developed in the lab by putting a known volume of water in the $20.4 \mathrm{~L}$ collection (buckets) and measuring the depth. Note that the collection devices (buckets) were tapered and the relationship between volume retained as depth increased was altered. If the measured depth in the field was less than or equal to $17.75 \mathrm{~cm}$, then the equation in the left figure was utilized to calculate the stormwater runoff volume. If measured depth was greater than $17.75 \mathrm{~cm}$, then the equation in the right figure was utilized to calculate the stormwater runoff volume.

\section{Data analysis}

For plant coverage data, a one-way analysis of variance (ANOVA) for a completely randomized design was used to test for differences between treatments and among treatments for each wall surface aspect. A Tukey's post-hoc test was then used to rank the differences at an alpha $(\alpha)$ of 0.05 (PROC GLM, SAS version 9.1).

For stormwater retention data, a one-way ANOVA for a completely randomized design was used to test for differences between treatments. A Tukey's post-hoc test was then used to rank differences at an $\alpha$ of 0.1 (PROC GLM, SAS version 9.1). An $\alpha$ of 0.1 was used in light of the low number of replicates, the large size of the green wall systems, the maximum capacity of the collection units being occasionally exceeded, and resulting additional experimental error.

\section{RESULTS}

\section{Plant coverage of wall surface}

Differences in plant wall surface coverage between treatments were found for the study period. On average, plant wall surface coverage for all planted treatments ranged from about $30 \%$ to $70 \%$ (Figure 4). S. kamtschaticum had superior wall surface coverage (70\%) compared to all other vegetated treatments. S. takesimensis and S. hybridum 'Immergrauch' with $42.5 \%$ and $36 \%$ coverage, respectively, were significantly lower than S. spurium, mixed Sedum species, and S. kamtschaticum. S. spurium and mixed Sedum species, with $62 \%$ and $60 \%$ coverage, respectively, had greater wall surface coverage than $S$. takesimensis and $S$. hybridum 'Immergrauch,' but lower wall surface coverage than S. kamtschaticum. 


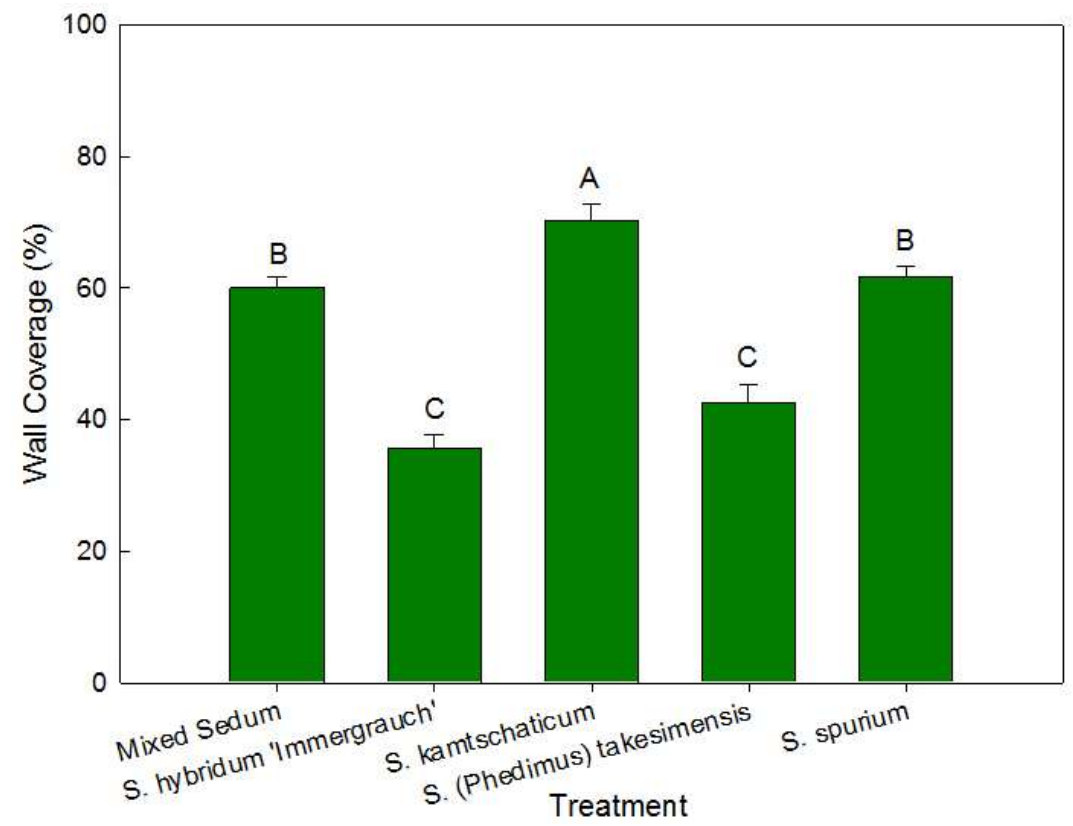

Figure 4. Average plant wall surface coverage for living wall systems for study period (8/10-9/11). Bars with different letters are significantly different $(\alpha<0.05$, error bars represent +1 SE). $n=120$.

Differences in plant wall surface coverage were found for every month except September 2010 (Figure 5). Wall surface coverage by plants was $<40 \%$ for all treatments except $S$. spurium (41\%) in March 2011, following winter foliage die-back. Wall surface coverage by plants was greater than $50 \%$ for all planted treatments excluding $S$. hybridum 'Immergrauch' (44\%) between June 2011 and September 2011. Wall surface coverage by S. kamtschaticum was significantly greater than one or more treatments for all months except September 2010 and March 2011.

Differences in plant wall surface coverage were also found between treatments among the four wall aspects during the study period. On the east aspect (Figure 6a), walls planted with $S$. kamtschaticum had greater wall surface coverage (72\%) than S. spurium, S. takesimensis and $S$. hybridum 'Immergrauch' walls (67\%, 36\% and 27\%, respectively). S. spurium had greater wall surface coverage than $S$. takesimensis and $S$. hybridum 'Immergrauch.' On the west aspect (Figure 6b), walls planted with $S$. kamtschaticum had greater wall surface coverage (73\%) than $S$. hybridum 'Immergrauch' walls (56\%). On the north aspect (Figure 6c), walls planted with $S$. kamtschaticum had greater wall surface coverage (83\%) than all other planted treatments. Walls planted with S. spurium and mixed Sedum had greater wall surface coverage (64\% and 54\%, respectively) than $S$. hybridum 'Immergrauch' and S. takesimensis walls (both 28\%). On the south aspect (Figure 6d), walls planted with mixed Sedum species had greater wall surface coverage (64\%) than S. takesimensis and S. hybridum 'Immergrauch' walls (40\% and 32\%, respectively). 


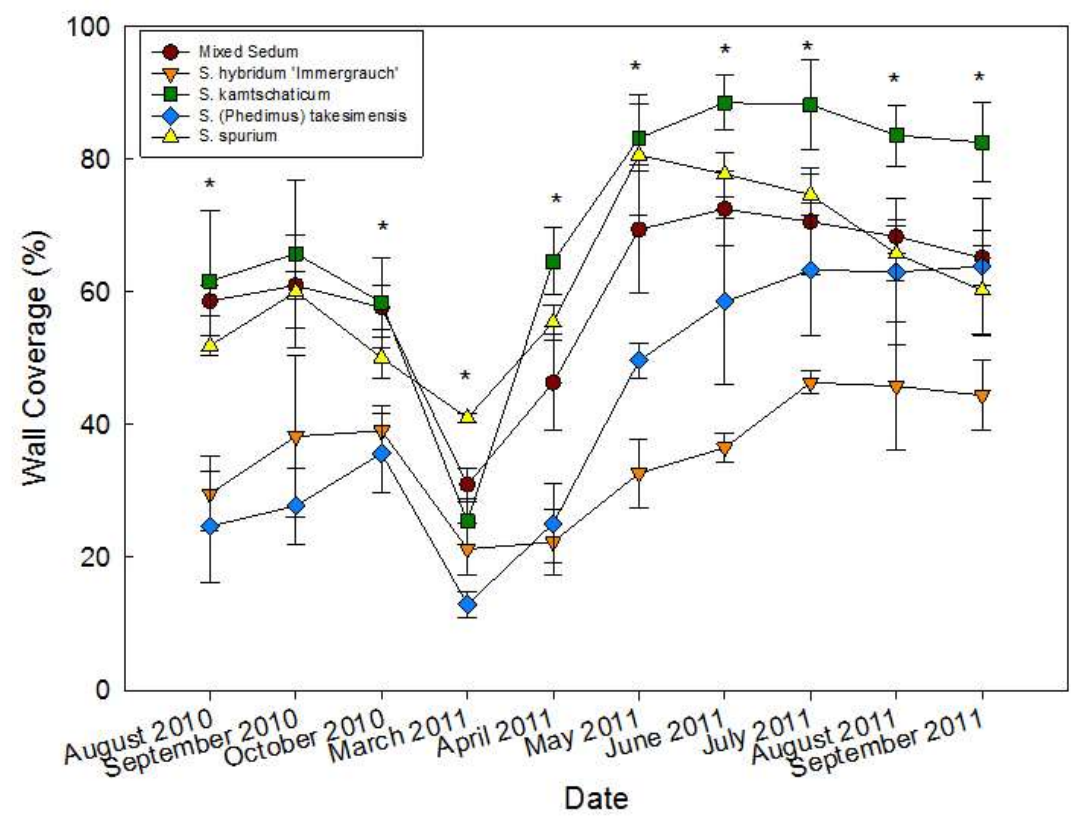

Figure 5. Percent plant wall surface coverage for living retaining wall systems for each month during the growing seasons $(8 / 10-10 / 10,3 / 11-9 / 11)$. An asterisk indicates a difference between treatments for that month $(\alpha<0.05$, error bars represent $\pm 1 \mathrm{SE})$.

\section{Stormwater retention}

From July 1, 2010 to September 15, 2011, a total of $149.1 \mathrm{~cm}$ of precipitation fell over the course of 81 precipitation events (Figure 7a,b) at this field site. Each living retaining wall received 5,334 $\mathrm{L}$ of precipitation during the study period. The smallest precipitation events for which data was collected occurred on October 10, 2010 and August 13, 2011, each producing only $0.13 \mathrm{~cm}$ of rainfall. The largest precipitation event occurred on August 19, 2010, producing $7.2 \mathrm{~cm}$ of rain. Approximately $50.6 \%$ of the events during the study period produced less than $1.27 \mathrm{~cm}$ of precipitation. Twenty percent of the precipitation events were greater than $2.54 \mathrm{~cm}$. The monthly precipitation depths $(\mathrm{cm})$ and the volume $(\mathrm{L})$ falling over the area of an individual green wall system were collected (Figure 8). The month of April 2011 had the most precipitation, $20.2 \mathrm{~cm}$, while August 2011 had the least precipitation, $2.0 \mathrm{~cm}$. 

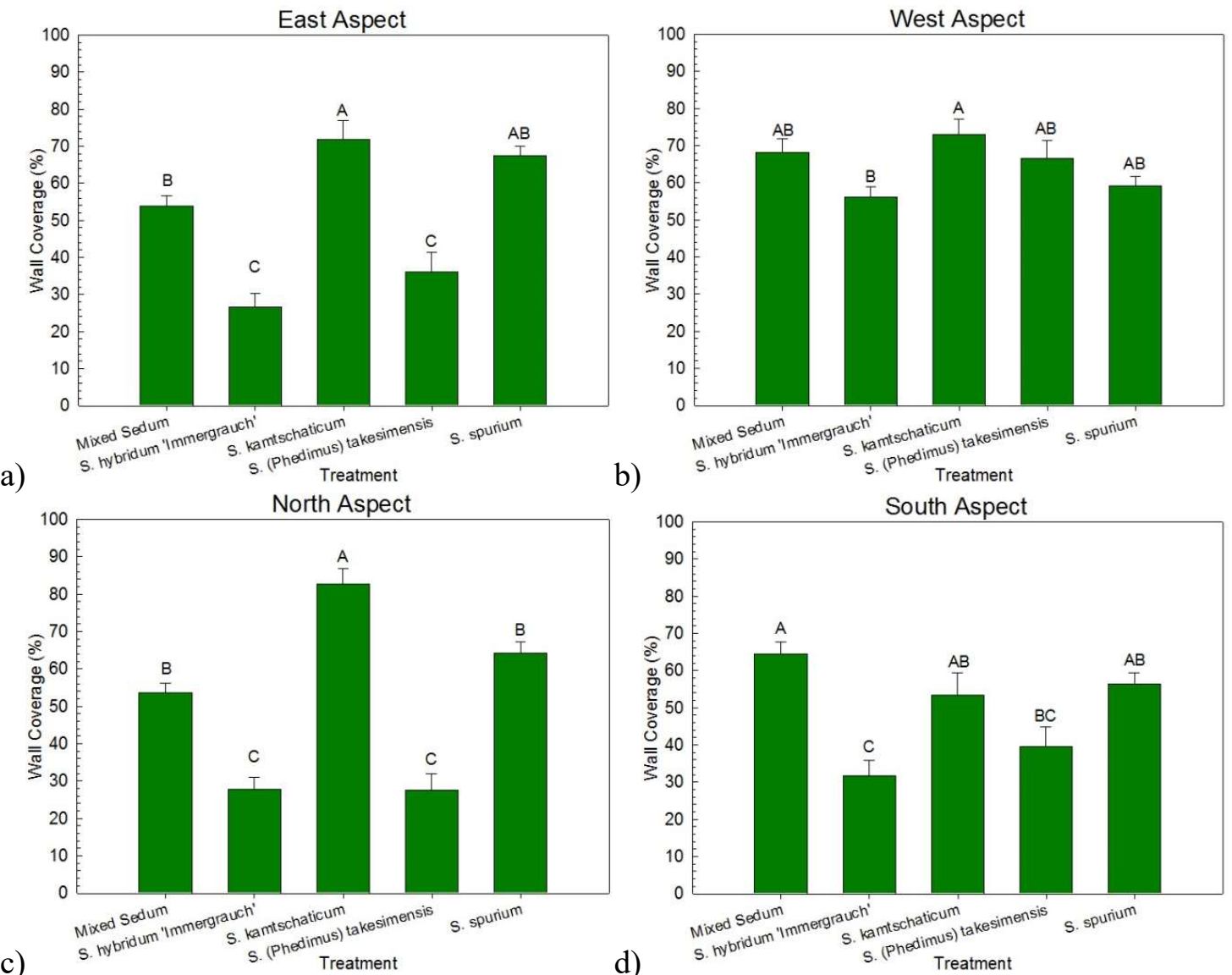

Figure 6. Average plant wall surface coverage for living retaining wall systems by aspect for study period (8/10-9/11). Figures represent wall surface coverage on east (a), west (b), north (c), and south (d) aspects. Bars with different letters are significantly different within each figure $(\alpha<0.05$, Error Bars represent $+1 \mathrm{SE}$ ). $n=30$ for each aspect.

a)

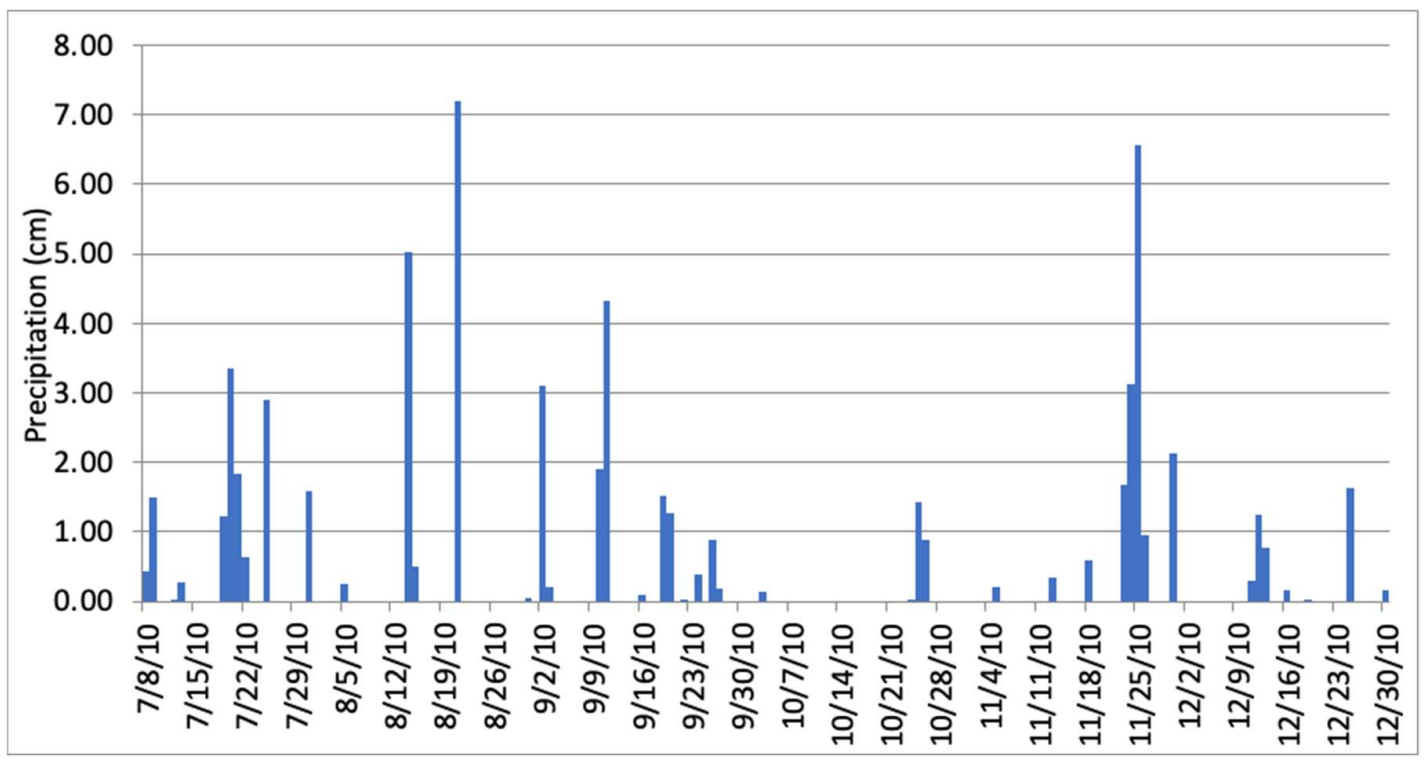




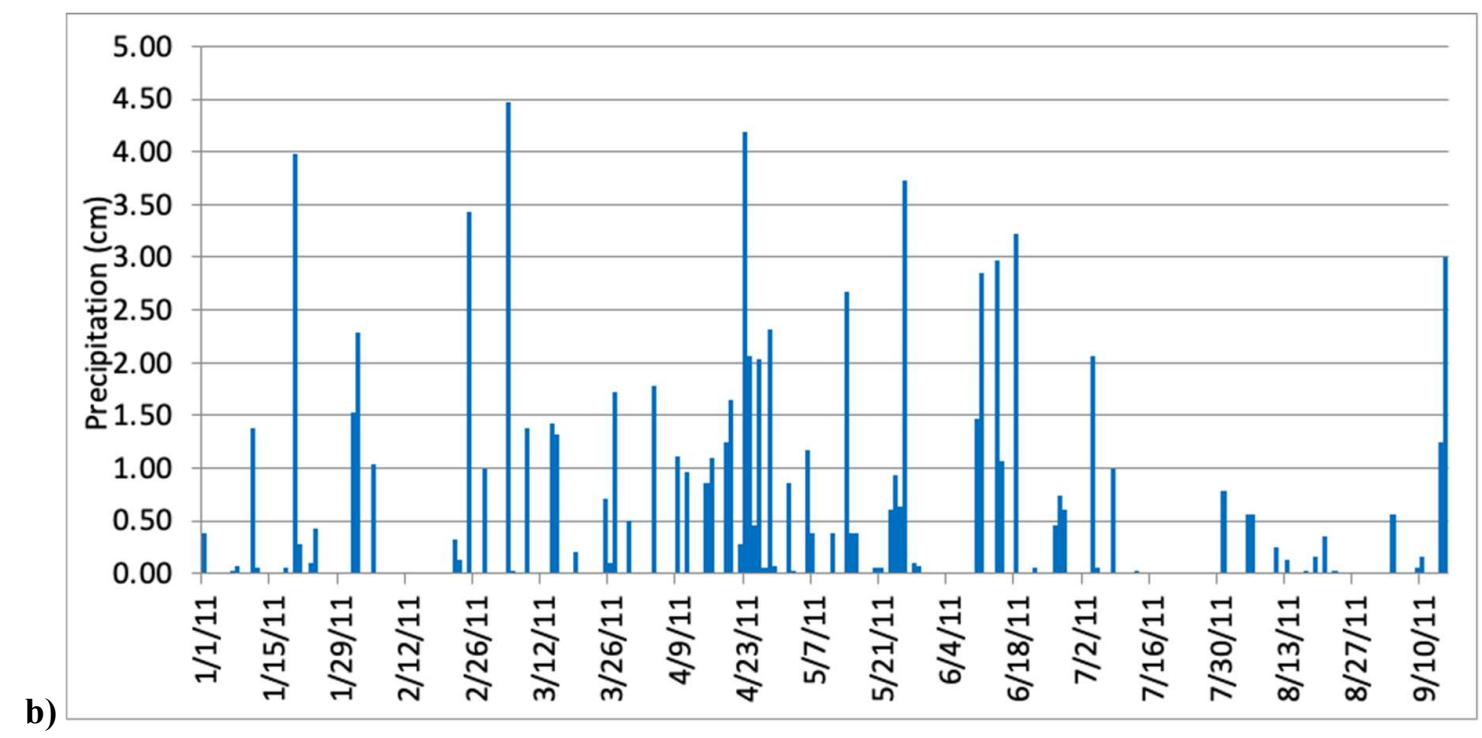

Figure $7 \mathbf{a} / \mathbf{b}$. Precipitation during the study period (7/01/10-12/31/10 and 1/1/11-9/15/11). Frozen precipitation was converted to liquid precipitation at a ratio of $1 \mathrm{~cm}$ solid $=0.1 \mathrm{~cm}$ liquid.

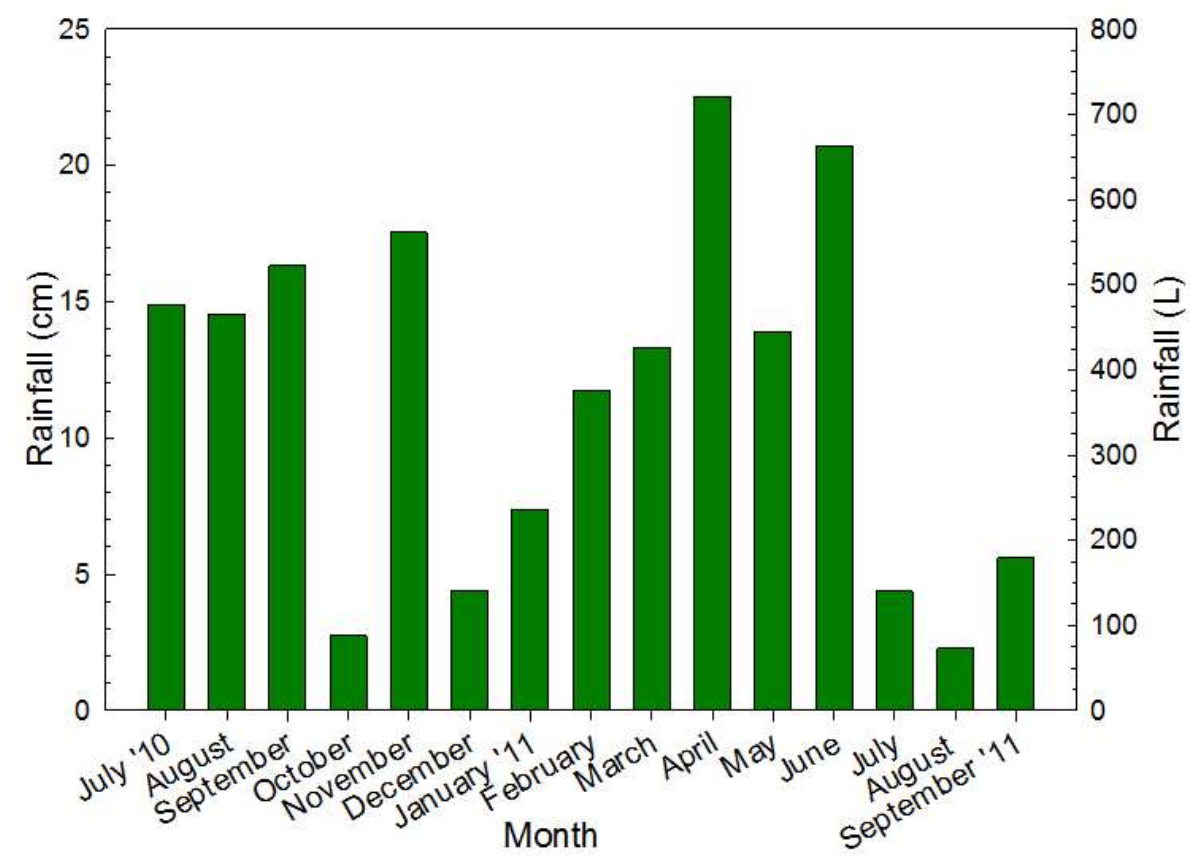

Figure 8. Rainfall $(\mathrm{cm})$ per month during the study period (7/01/10-9/15/11). Rainfall volume (L) falling over a representative $2.13 \mathrm{~m}$ diameter living wall.

Average stormwater volume collected by plant species for the study period is depicted (Figure 9). Living retaining walls planted with $S$. takesimensis had 4.9 L less collected, on average, than any other treatment ( $\geq 7 \mathrm{~L}$ on average). Less stormwater was collected from living retaining walls planted with $S$. hybridum 'Immergrauch,' which generated $7.8 \mathrm{~L}$ on average, than the unplanted wall and the wall systems planted with S. spurium. Stormwater collected from living retaining walls planted with $S$. spurium was 10.7 L on average, nearly the same as the control, which was $11 \mathrm{~L}$ on average. 


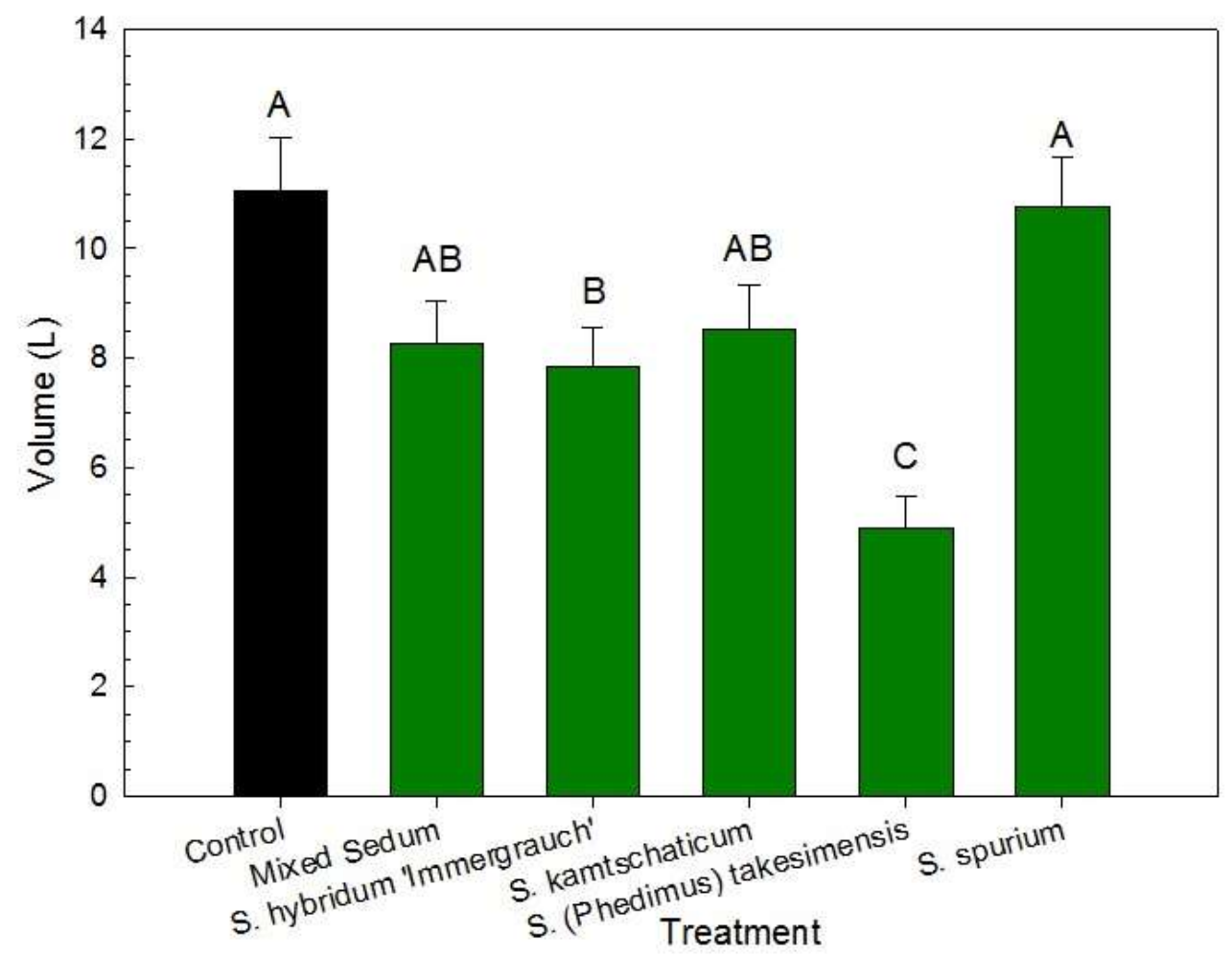

Figure 9. Average stormwater volume (L) collected per event by plant species for the study period (7/1/11-9/15/11). Bars with different letters are significantly different within figure $(\alpha<0.1$, Error Bars represent $+1 \mathrm{SE}) . n=243$ each planted treatment, $n=162$ control.

The percent retention of experimental living retaining wall systems planted with different plant species is shown (Figure 10). On average, all treatments (including unplanted wall systems) retained more than $80 \%$ of stormwater. Experimental living retaining walls planted with $S$. takesimensis retained $93 \%$ of the stormwater while the unplanted (control) experimental retaining walls retained $83 \%$. Experimental living retaining walls planted with $S$. takesimensis retained more stormwater than experimental living retaining walls planted with the other plant species - S. spurium, S. kamtschaticum, and mixed Sedum species. 


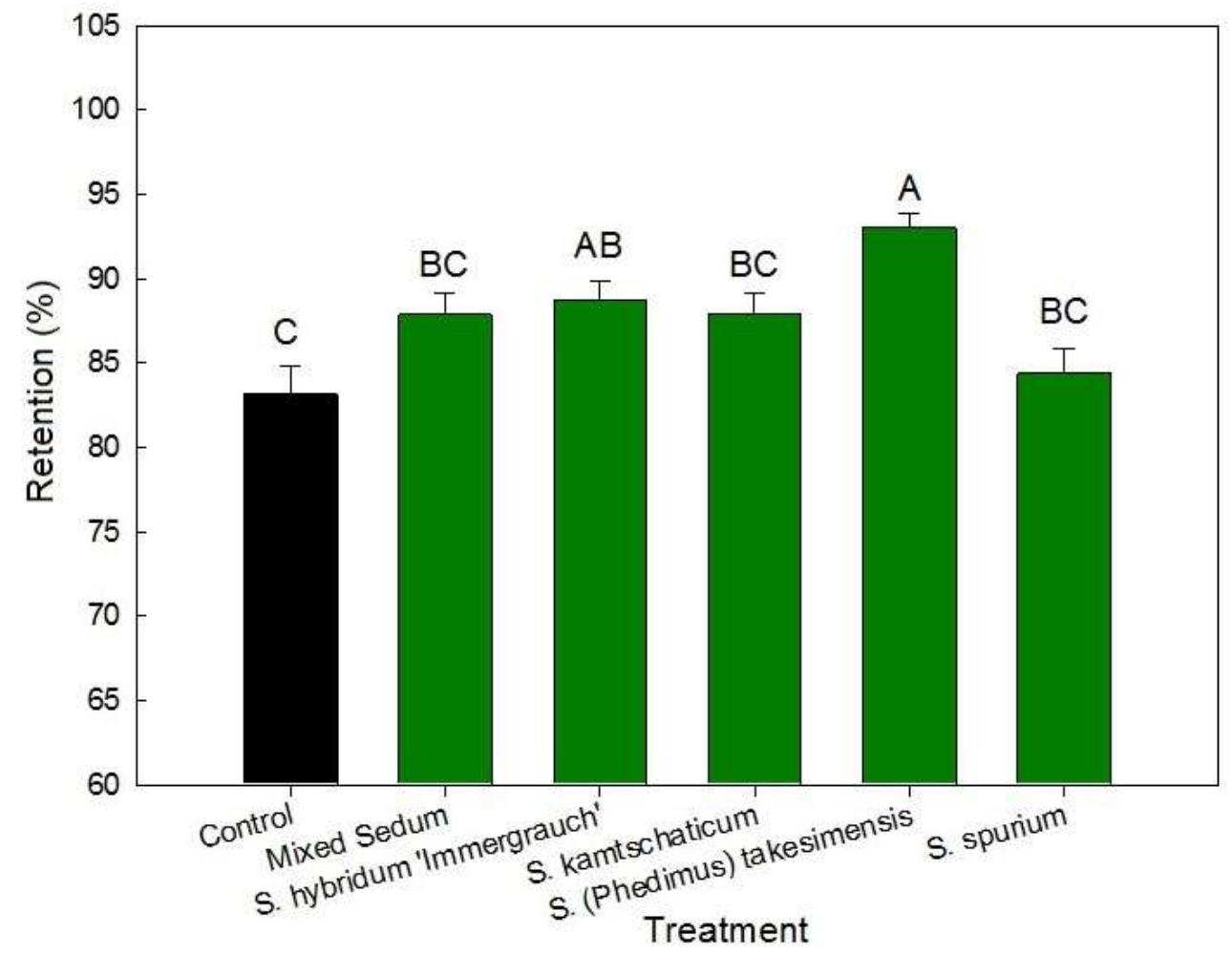

Figure 10. Percent stormwater retention by experimental living retaining wall systems planted with different plant species for study period (7/1/11-9/15/11). Bars with different letters are significantly different within figure $(\alpha<0.1$, Error Bars represent +1 SE). $n=234$ each planted treatment, $n=156$ control.

Individual measurements were taken following a rainfall event on September 14, 2011 following a 72-day drought at this study site (Figure 11). During the drought period, only 3.9 $\mathrm{cm}$ of precipitation fell; no measurable volumes were collected. However, on September 14, $4.24 \mathrm{~cm}$ of precipitation fell from morning to early afternoon. No volume was collected from any treatment following the storm that day. By 9 a.m. the following morning, stormwater volume collected from the unplanted wall was the largest, $1.1 \mathrm{~L}$, followed by wall systems planted with $S$. spurium, from which $0.54 \mathrm{~L}$ was collected.

In contrast, on April 23, 2011, a similarly sized rainfall event of $4.19 \mathrm{~cm}$ was recorded (Figure 12), but a total of $3 \mathrm{~cm}$ of rain had fallen the previous three days. With the preceding wet period, an order of magnitude more volume was collected, in the range of $25.7 \mathrm{~L}$ to $33.3 \mathrm{~L}$. 


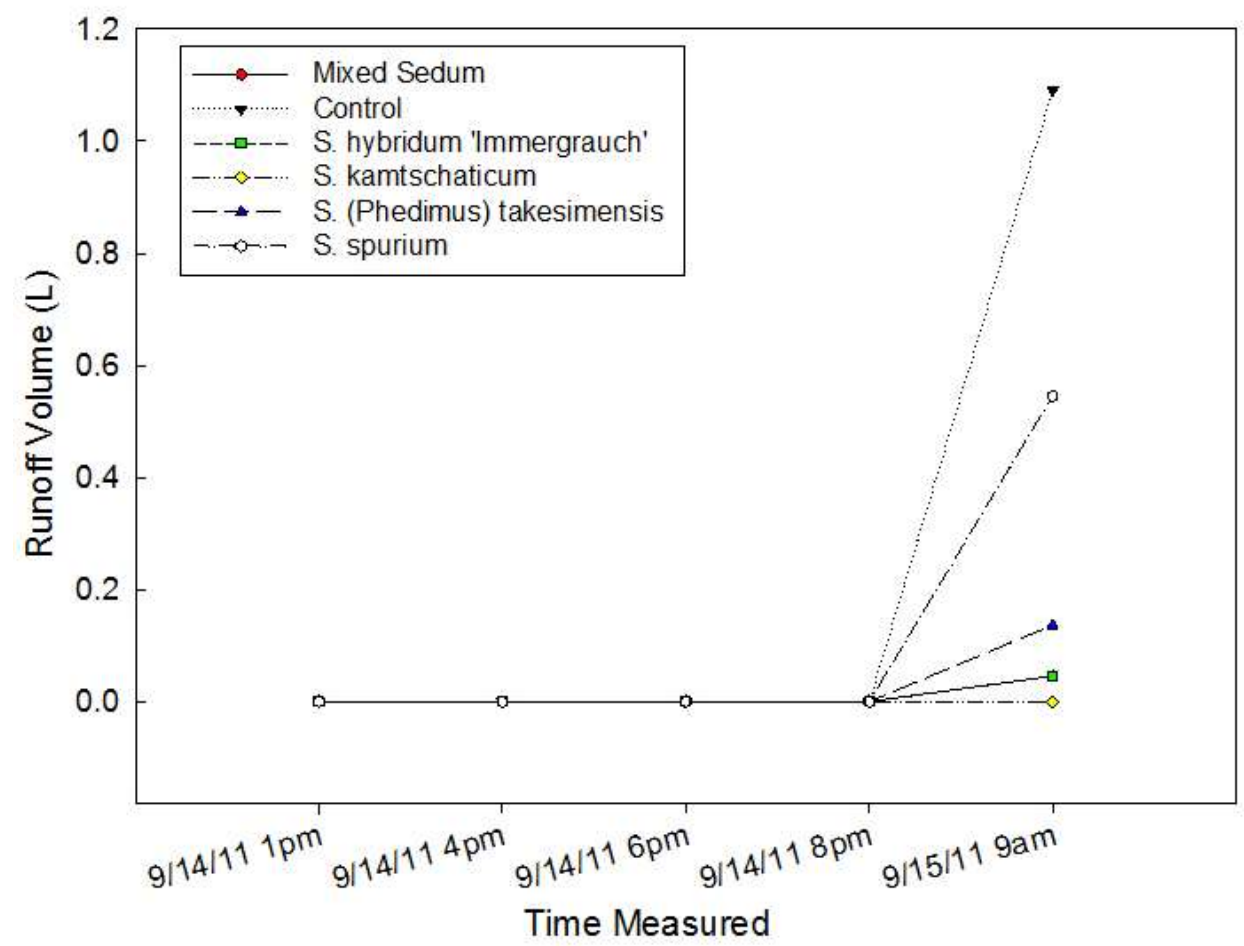

Figure 11. Collected stormwater volume for $9 / 14 / 11$ rainfall event $(4.24 \mathrm{~cm})$. Discharged volumes (following a $4.24 \mathrm{~cm}$ precipitation event) were recorded at 1:00 p.m., 4:00 p.m., 6:00 p.m., and 8:00 p.m. on 9/14/11 and again at 9:00 a.m. on 9/15/11.

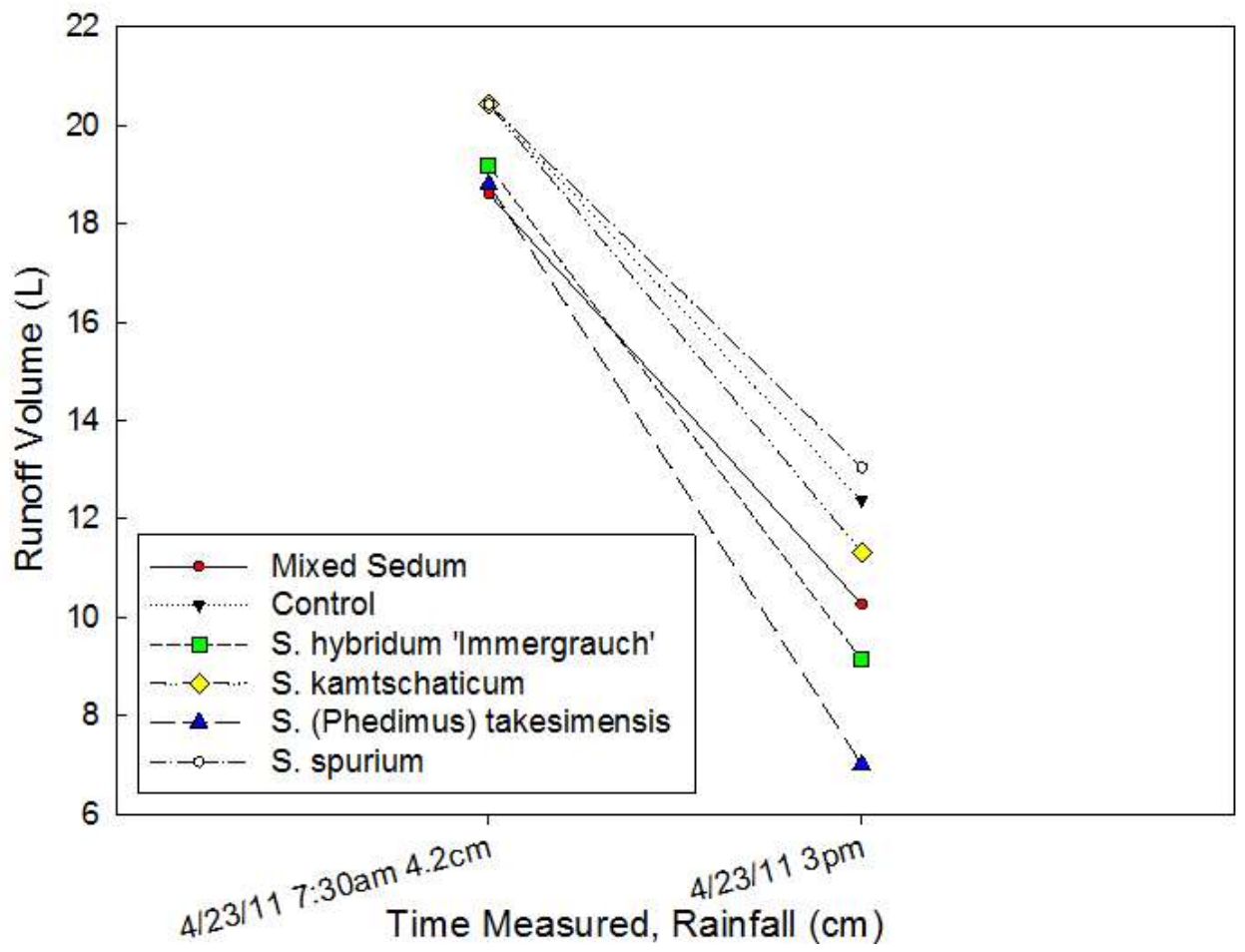

Figure 12. Collected stormwater volume for $4 / 23 / 11$ rainfall event $(4.19 \mathrm{~cm})$. Discharged volumes (following a $4.19 \mathrm{~cm}$ precipitation event) were recorded at 7:30 a.m. and 3:00 p.m. on 4/23/11. 


\section{DISCUSSION}

\section{Plant coverage of wall surface}

The most successful treatment in terms of plant wall surface coverage was S. kamtschaticum (70\%). Living retaining walls planted with $S$. kamtschaticum had the greatest percent wall surface coverage on east (72\%), west (73\%), and north (83\%) wall aspects. Perhaps the success of $S$. kamtschaticum stems from its creeping growth habit, its ability to rapidly spread and fill an area, and its tolerance to shade, rainy summers, and frosty, rainy winters (Stephenson 1994). $S$. kamtschaticum has also been found to survive in drought conditions, 80 days without water, during a study in Michigan (Snodgrass and Snodgrass 2006). S. spurium also appeared relatively successful in covering the living retaining walls. Other studies have found S. spurium to be well-suited for green roof media (Getter and Rowe 2008, Wolf and Lundholm 2008), including a 16 month green roof establishment study at SIUE (Kaufman 2008).

One of the least successful treatments in terms of plant wall surface coverage was $S$. hybridum 'Immergrauch' with only $36 \%$ wall surface coverage on average. S. hybridum 'Immergrauch' covered the top and pockets of the systems laterally and even occasionally expanded into the adjacent ground-level soil, but plants did not grow high enough to cover the wall block above or cascade down to adequately cover the wall block face below. During winter 2010, wall surface coverage by S. hybridum 'Immergrauch' dropped below 30\%. During the summer 2011 drought, $S$. hybridum 'Immergrauch' plant wall surface coverage remained consistently below $50 \%$. In a green roof study at SIUE, S. hybridum 'Immergrauch' appeared to require at least 10 $\mathrm{cm}$ of growing media to survive in a built-in-place green roof system; $5 \mathrm{~cm}$ of growing media appeared to be inadequate (Forrester 2007). The pockets of the living wall blocks are approximately $7.5 \mathrm{~cm}$ deep, perhaps contributing to the subpar growth performance of $S$. hybridum 'Immergrauch'.

Plant coverage varied noticeably throughout the study period. Influences on coverage include season, time since planting, and water availability. Winter foliage dieback affected all planted treatments. All planted treatments except $S$. spurium fell to $<40 \%$ plant coverage by March 2011. Coverage measurements for $S$. spurium remained relatively high (41\%), likely because tall seed heads persisted throughout the majority of winter. Drought conditions from July to mid-September 2011 likely contributed to stagnated growth or slight decreases in plant coverage. Nonetheless, most treatments performed better in 2011 than in 2010, albeit 2010 data only includes August through October. As the plants continue to establish their root systems and spread vegetatively across the green wall surfaces, greater wall surface coverage is ultimately expected.

\section{Stormwater retention}

The amount of precipitation and the timing of precipitation events were major factors impacting stormwater retention by the living retaining wall system evaluated in this study. Despite relatively unimpressive plant coverage ( $36 \%$ and $27 \%$, respectively), S. hybridum 'Immergrauch' and S. takesimensis retained more stormwater per event compared to the other planted wall treatments and the unplanted control wall. Planted experimental living wall 
systems retained on average $88 \%$ of the precipitation in this study while the unplanted wall retained 83\%. However, only living retaining walls planted with S. takesimensis (retaining 93\% of the stormwater) were statistically greater than the retention of unplanted (control) retaining walls (retaining $83 \%$ ).

The retention values are relatively high given the multitude of closely-timed precipitation events and the experimental design of the walls. One possible explanation is that approximately $50.6 \%$ of the precipitation events recorded were light $(<1.27 \mathrm{~cm})$. A $25 \%$ sloped extensive green roof system in Michigan reduced stormwater runoff by $75.3 \%$ during their study period. The 3-year-old sloped green roof systems retained $94.2 \%$ for light rains $(<0.2 \mathrm{~cm})$ and $63.3 \%$ for heavier rains $(>1 \mathrm{~cm})$ (Getter et al. 2007). In general, intensive green roofs retain $75 \%$ of rainfall while extensive roofs retain $45 \%$ of stormwater (Czemiel Berndtsson 2010). The experimental living retaining wall systems often performed more like intensive green roofs. The large volume of core-fill material within each living wall system in this study is likely the reason for the significant stormwater retention.

Out of 81 precipitation events, 21 events were completely retained by the planted living walls and 19 events were completely retained by every living wall system at this site. The largest precipitation event for which the living walls had $100 \%$ retention was $1.8 \mathrm{~cm}(0.72 \mathrm{in})$ on November 22, 2010. This is comparable to a study on modular extensive green roofs. In that study, a simulated $1.27 \mathrm{~cm}$ rain event yielded 100\% stormwater retention (Hilten et al. 2008). Without the large center filled with media, we still expect the wall pockets to retain a substantial amount of stormwater.

In the present study, the $4.2 \mathrm{~cm}$ precipitation event on September 14, 2011 also had excellent retention following an enduring summer drought at this field site. For that singular event, the planted living walls retained $99.9 \%$ of the stormwater while the unplanted walls retained $99.3 \%$.

Under less arid conditions, the experimental living retaining walls retained far less following such a substantial precipitation. During a similar rain event on April 23, 2011 for example, stormwater collected for planted and unplanted living wall systems were $80 \%$ and $78 \%$, respectively. The April 2011 event, producing $4.19 \mathrm{~cm}$ of precipitation, was preceded by $3 \mathrm{~cm}$ of rainfall over the previous few days. During the first measurement (7:30 a.m.) stormwater collection units for many of the experimental living wall systems in this study had already reached capacity $(20.4 \mathrm{~L})$.

The overall stormwater retention values are relatively high for several reasons. First, each cylindrical system had a large top surface with the radius simulating the top surface of a retaining wall as installed in the field. The large amount of growth media and core fill material offer exceptional storage capacity for precipitation. Second, several individual rain events resulted in $100 \%$ retention, perhaps because $50.6 \%$ of the recorded precipitation events were relatively light $(\leq 1.27 \mathrm{~cm})$. Third, instead of running off, precipitation also likely pooled in the pockets of the blocks, in the growth media, on the surface of the systems, on the surface of the 
vegetation, on the impermeable layer, and in some of the drainage piping. Additionally, unknown quantities of precipitation evapotranspired, or in the case of snow, sublimed.

VanWoert et al. (2005) argued that vegetative cover plays an important role in erosion control and temperature moderation, but that media is perhaps the most important factor determining stormwater benefits. With only a $10 \%$ difference in retention between experimental walls with the best performing plant, $S$. takesimensis, and unplanted experimental living walls, media properties may indeed be important for the hydrological performance of living retaining wall systems.

Planted living retaining wall systems, as examined in this study, may serve as an alternative environmental mitigation tool for urban areas. Results from this study indicate that planted living retaining walls may offer stormwater benefits compared to retaining walls left unplanted.

In terms of stormwater retention, certain Sedum treatments fared better than the unplanted living walls. This study found significant differences in mean stormwater retention among six planted treatments. Living retaining walls planted with $S$. takesimensis increased stormwater retention more effectively than unplanted retaining walls and other planted treatments including $S$. spurium, mixed Sedum, and S. kamtschaticum. The unplanted walls retained $10 \%$ less stormwater per rain event than $S$. takesimensis walls, indicating that the plants are an important component of the system.

This study also found significant differences in percent plant coverage of planted treatments for the study period August 10 to September 11, 2010. Experimental living retaining walls planted with $S$. kamtschaticum had greater surface coverage (70\%) than treatments planted with $S$. takesimensis (42.5\%) or S. hybridum 'Immergrauch' (36\%). Further study could determine the performance of living retaining walls with a more conventional design (i.e., single aspect vs. four aspects against a slope), over a longer time period, walls planted with other vegetated treatments, and walls featuring different fill materials.

\section{CONCLUSIONS}

Constricted city cores and expanding suburban areas must find innovative ways to retain stormwater near where it falls. A multitude of green infrastructure technologies can perform in concert to address these concerns. For example, a series of management tools, including green roofs, rain barrels, grass swales, wetlands, ponds, and open channels, can be incorporated into existing urban neighborhoods to increase stormwater retention and reduce CSOs (Villarreal et al. 2004). Living retaining walls, as examined in this study, may serve as another useful environmental mitigation tool for urban areas. Overall, it appears that a planted living retaining wall system may offer stormwater retention benefits compared to living retaining walls left unplanted. This study also demonstrates the importance of plant selection in optimizing the environmental benefits of living retaining wall systems.

The ability of a vegetative treatment to cover a wall surface is often associated with better environmental performance, not to mention enhanced aesthetics and improved urban 
biodiversity. The assessment of plant wall surface coverage in this study revealed that $S$. kamtschaticum had better overall wall surface coverage (70\%) than all other planted living walls. S. kamtschaticum performed very well, especially in shaded wall aspects, throughout the study, despite dramatically reduced wall surface coverage following winter dieback. $S$. takesimensis, on the other hand, performed relatively poorly during the 2010 growing season and following winter dormancy, but experienced improved performance during the 2011 growing season and adequately tolerated the dry summer 2011 period.

Green infrastructure can be designed to mitigate stormwater runoff generated by the extraordinarily high impervious surface area of urbanized watersheds. Living retaining wall systems planted with $S$. takesimensis retained stormwater more effectively than the unplanted living walls and other planted treatments, including S. spurium, mixed Sedum, and S. kamtschaticum. The unplanted living retaining walls retained $10 \%$ less stormwater per rain event than living retaining walls planted with $S$. takesimensis. Performance may be related to plant root system characteristics as well as the choice of growth media and core fill material, coal bottom ash in this study, as well as the intensity and timing of precipitation. Based on observations from this Midwestern study on a living retaining wall system, S. kamtschaticum is recommended to optimize wall surface coverage while $S$. takesimensis is recommended to optimize stormwater retention benefits. Perhaps mixed plantings of stonecrops that emphasize both species could be used to mitigate stormwater runoff, provide maximum coverage, and enhance aesthetic appeal of living retaining wall systems.

\section{ACKNOWLEDGMENTS}

This project was an MS Thesis project of Mr. Mark Ostendorf conducted under the direction of faculty in the SIUE Living Architecture Research Program. The faculty/student research group is thankful for the support of the Office of the Vice-Chancellor of Administration in approving the on-campus study-site location. We also thank the Department of Environmental Sciences and the SIUE Graduate School for the Teaching Assistantship for Mark that permitted him to conduct this study. We are forever indebted to Mark Woolbright the inventor of the Hercules ${ }^{\mathrm{TM}}$ Living Wall Block and to St. Louis Retaining Wall Company (12901 Saint Charles Rock Road, St. Louis, MO) for the donation of project materials and project installation (on days it reached $\left.105-107^{\circ} \mathrm{F}\right)$.

\section{LITERATURE CITED}

Azkorra, Z., G. Perez, J. Coma, L.F. Cabeza, S. Bures. J.E. Alvaro, A. Erkoreka and M. Urrestarazu. 2015. "Evaluation of green walls as a passive acoustic insulation system for buildings." Applied Acoustics, 89: 46-56.

Carter, T. and C.R. Jackson. 2006. "Vegetated roofs for stormwater management at multiple spatial scales." Landscape and Urban Planning, 80: 84-94.

Czemiel Berndtsson, J. 2010. "Green roof performance towards management of runoff water quantity and quality: a review." Ecological Engineering, 36: 351-360.

Forrester, K. 2007. "Evaluation of stormwater runoff from a Midwest green roof system." Master's Thesis. Southern Illinois University Edwardsville, Edwardsville, IL.

Getter, K.L. and D.B. Rowe. 2008. "Media depth influences Sedum green roof establishment." Urban Ecosystems, 11: 361-372. 
Getter, K.L., D.B. Rowe and J.A. Andresen. 2007. "Quantifying the effect of slope on extensive green roof stormwater retention." Ecological Engineering, 31: 225-231.

Hilten, R.N., T.M. Lawrence and E.W. Tollner. 2008. "Modeling stormwater runoff from green roofs with HYDRUS-1D.” Journal of Hydrology, 358: 288-293.

Kaufman, S. 2008. "Plant species evaluation for extensive green roof applications in the Midwestern United States.” Master's Thesis. Southern Illinois University Edwardsville, Edwardsville, IL.

Li, Y. and C. Wang. 2009. "Impacts of urbanization on surface runoff of the Dardenne Creek Watershed, St. Charles County, Missouri." Physical Geography, 30: 556-573.

Manso, M. and J. Castro-Gomes. 2015. "Green wall systems: A review of their characteristics." Renewable and Sustainable Energy Reviews, 41: 863-871.

Mueller, G.D. and A.M. Thompson. 2009. "The ability of urban residential lawns to disconnect impervious area from municipal sewer systems." Journal of the American Water Resources Association, 45: 1116-1126.

Parikh, P., M.A. Taylor, T. Hoagland, H. Thurston and W. Shuster. 2005. "Application of market mechanisms and incentives to reduce stormwater runoff: an integrated hydrologic, economic, and legal approach." Environmental Science and Policy, 8: 133-144.

Population Division of the Department of Economic and Social Affairs of the United Nations Secretariat, World Population Prospects: The 2006 Revision and World Urbanization Prospects: The 2007 Revision. 2007. Retrieved October 03, 2011. http://esa.un.org/unup/.

Romanova, A., K.V. Horoshenkov and A. Hurrell. 2019. "An application of a parametric transducer to measure acoustic absorption of a living green wall." Applied Acoustics, 145: 89-97.

Snodgrass, E.C., and L.L. Snodgrass. 2006. Green roof plants: A resource and planting guide. Timber Press Inc. Portland, OR.

Stephenson, R. 1994. "Sedum: Cultivated Stonecrops." Timber Press, Inc. Portland, OR.

USEPA. 2006a. Dry Ponds. Retrieved January 26, 2012. http://cfpub.epa.gov/npdes/stormwater/menuofbmps/index.cfm?action=browse \&Rbutton=detail \&bmp $=67$.

USEPA. 2006c. Wet Ponds. Retrieved January 26, 2012. http://cfpub.epa.gov/npdes/stormwater/menuofbmps/index.cfm?action=factsheet results\&view $=$ specific \&bmp $=68$.

VanWoert, N.D., D.B. Rowe, J.A. Andresen, C.L. Rugh, R.T. Fernandez and L. Xiao. 2005. "Green roof stormwater retention: effects of roof surface, slope, and media depth." Journal of Environmental Quality, 34: 1036-1044.

Villarreal, E.L., A. Semadeni-Davies and L. Bengtsson. 2004. "Inner city stormwater control using a combination of best management practices." Ecological Engineering, 22: 279-298.

Wolf, D. and J.T. Lundholm. 2008. "Water uptake in green roof microcosms: Effects of plant species and water availability." Ecological Engineering, 33: 179-186. 